\title{
PEMBUATAN SEDIAAN BALSEM STICK DARI SEREH (Cymbopogon citratus (DC.) Stapf) SEBAGAI AROMATERAPI
}

\author{
Okto Hebron Purba, Nola Thania Tumanggor, Anggun Syafitri, Linta \\ Meliala, Delisma Masauli Simorangkir \\ Fakultas Farmasi Institut Kesehatan Deli Husada Deli tua \\ Jalan Besar No 77 Delitua Kab. Deli Serdang 20355, Sumatera utara, \\ Indonesia \\ e-mail :Oktopurba@gmail.com
}

\begin{abstract}
Introduction: Lemongrass plants contain essential oils that can be used as aromatherapy. In the context of efforts to improve public health services in Indonesia, traditional medicine has the opportunity as one of the potential alternative treatments and alternative therapeutic for all people. Society uses traditional medicine in the form of herbal medicine, stew, juice or by rubbing directly on the affected part in medicine. Method: Sample in this study was African leaves and palm leaveswhich were taken purposively without comparing samples from other regions, To get the essential oil of lemongrass done by distillation. Result: Aromatherapy balm from essential oil is formulated with some concentrations of $0 \%, 15 \%, 20 \%$ and $25 \%$ of the evaluation of balm which has been done to 3 qualified balm formulas and has good physical quality. Concludes: Citronella essential oil can be made into a supply of balm stick with various concentrations, namely $15 \%, 20 \%$ and $25 \%$. Stick balm made from essential oils of lemongrass can give an aromatherapy effect which is characterized by a refreshing aroma when inhaling the balm preparations and can provide a warm sensation. The best concentration as an aromatherapy stick balm preparation is $25 \%$ because it gives the highest aroma and test preferences.
\end{abstract}

Keywords: Aromatherapy, lemongrass, essential oil

\section{PENDAHULUAN}

Dalam peningkatan pelayanan kesehatan masyarakat di Indonesia, obat tradisional berpeluang sebagai salah satu pilihan pengobatan yang cukup potensial. Dengan keberagaman jenis tanaman yang ada, dapat membuka peluang yang luas untuk memperoleh obat baru. Dikalangan masyarakat Indonesia, tanaman obat dijadikan sebagai obat tradisional karna memiliki kelebihan yaitu mudah diperoleh, harganya murah dan dapat dibuat sendiri (Zulkarnain \& Amirullah, 2012). 


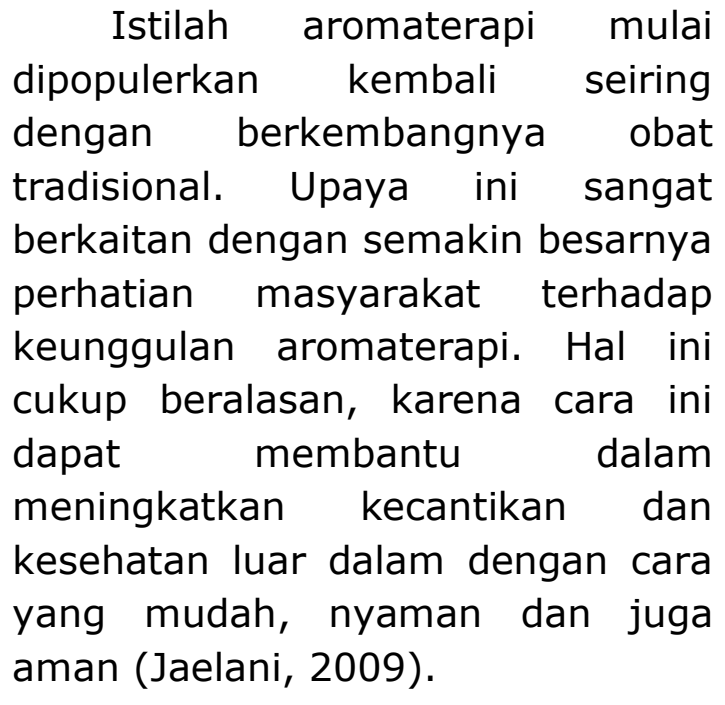

Salah satu tumbuhan yang banyak ditemukan dan memiliki banyak manfaat, yaitu tanaman sereh. Sereh mengandung metabolit sekunder, yaitu flavonoid, alkaloid, saponin dan steroid (Hendrik, dkk, 2013). Dalam sereh, kandungan yang sering digunakan adalah minyak atsirinya. Untuk memanfaatkan kegunaan dari sereh tersebut, maka akan diolah untuk diambil minyak atsirinya. (Jumardin, dkk, 2015). Minyak atsiri merupakan zat yang memberikan aroma pada tumbuhan. Saat ini minyak atsiri telah digunakan sebagai parfum, kosmetik bahan tambahan makanan dan obat (Prabandari, 2017).

Balsem merupakan sediaan
yang penggunaannya dengan
dioleskan ke kulit dengan tangan
sehingga dapat mengotori dan
memberikan rasa panas yang sulit
hilang. Bentuk sediaan balsem yang
dioleskan dengan tangan ini
diperlukan suatu inovasi yaitu
sediaan balsem stick sebagai
aromaterapi yang memiliki sifat

menghangatkan, menenangkan dan juga memiliki aroma yang menyegarkan (Yati, dkk, 2018). Balsem yang oleh sebagian orang sebelumnya dianggap "kuno" dan biasanya digunakan oleh orangtua, kini semakin elegan dan kekinian dengan bentuk balsem stick yang praktis untuk digunakan dan dapat digunakan oleh siapa saja (Pibriani, dkk, 2012).

\section{METODE}

Penelitian ini menggunakan metode eksperimental, yang dimulai dengan pengumpulan dan pengolahan sampel, karakterisasi simplisia, skrining fitokimia, pembuatan sediaan balsem stick dan pengujian sediaan.

Pembuatan sediaan balsem stick dilakukan di Laboratorium Teknologi Sediaan Farmasi, Fakultas Farmasi, Institut Kesehatan Deli Husada, Deli Tua. Sampel diambil dengan metode purposive dengan tanpa membandingkan sampel dengan tumbuhan yang sama di tempat yang lain.

\section{Alat dan Bahan}

Alat yang digunakan dalam penelitian ini adalah, batang pengaduk, timbangan elektrik, beaker gelas, cawan penguap, erlenmeyer, gelas ukur, kertas perkamen, kertas saring, corong pisah, tabung reaksi, rak tabung, alumunium foil, spatula, sudip, penanggas air, gunting, tissue, penjepit tabung, hot plate, lumpang, alu, pipet tetes, corong, 
satu set alat destilasi, $\mathrm{pH}$ meter, wadah balsem stick.

Bahan yang digunakan dalam penelitian ini adalah Aquades, daun sereh, toluen, air suling, kloroform, asam klorida, pereaksi LP Mayer, LP Bouchardat, LP Dragendorf, serbuk magnesium, alkohol, n-heksan, asam asetat anhidrat, asam sulfat pekat, timbal (II) asetat, isopropanol, natrium sulfat anhidrat, metanol, LP Molisch, pirogalol, tembaga (II) sulfat, minyak atsiri sereh, aquadest, vaselin album, menthol, oleum menthae, cera alba, paraffin liquid.

\section{Prosedur Pembuatan Sediaan Balsem stick}

Tabel 1. Formulasi Balsem

Aromaterapi

\begin{tabular}{|c|c|c|c|c|}
\hline Bahan & F I & F II & F III & $\begin{array}{c}\text { F } \\
\text { IV }\end{array}$ \\
\hline $\begin{array}{c}\text { Minyak } \\
\text { atsiri } \\
\text { Sereh }\end{array}$ & $0 \%$ & $\begin{array}{l}15 \\
\%\end{array}$ & $20 \%$ & $\begin{array}{l}25 \\
\%\end{array}$ \\
\hline Parrafin & $4 \mathrm{gr}$ & $4 \mathrm{gr}$ & $4 \mathrm{gr}$ & $4 \mathrm{gr}$ \\
\hline Menthol & $3 \mathrm{gr}$ & $3 \mathrm{gr}$ & $3 \mathrm{gr}$ & $3 \mathrm{gr}$ \\
\hline $\begin{array}{c}\text { Ol. } \\
\text { Menthae }\end{array}$ & $3 \mathrm{gr}$ & $3 \mathrm{gr}$ & $3 \mathrm{gr}$ & $3 \mathrm{gr}$ \\
\hline $\begin{array}{l}\text { Vaseline } \\
\text { Album }\end{array}$ & $\begin{array}{l}10 \\
\mathrm{gr}\end{array}$ & $\begin{array}{l}10 \\
\mathrm{gr}\end{array}$ & $10 \mathrm{gr}$ & $\begin{array}{l}10 \\
\mathrm{gr}\end{array}$ \\
\hline
\end{tabular}

Keterangan:

- F1 = Balsem stick tanpa minyak atsiri sereh

- F2 = Balsem stick dengan 15\% minyak atsiri sereh

- F3 = Balsem stick dengan 20\% minyak atsiri sereh.
- $\mathrm{F} 4=$ Balsem stick dengan 25\% minyak atsiri sereh.

Timbang semua bahan seperti paraffin liquid, vaselin album, menthol, dan cera alba kemudian leburkan diatas penangas air, setelah semua bahan sudah lebur, dimasukkan masing-masing minyak atsiri dengan konsentrasi $0 \%$ (0 $\mathrm{mL}), 15 \%$ (3 mL), 20\% (4 mL) dan 25\% (5 mL) kemudian aduk sampai homogen dan biarkan hingga dingin dan masukkan kedalam wadah balsem stick.

\section{Gambar 1. Sediaan Balsem Stick}

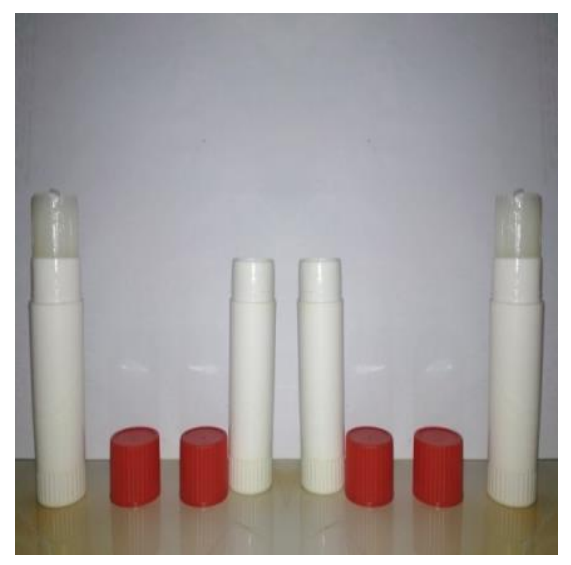

\section{Pengujian Evaluasi Sediaan}

\section{Uji organoleptis}

Pengujian

organoleptik dilakukan dengan cara mengamati sediaan balsem stick dari bentuk, warna dan aroma dari setiap masing-masing sediaan yang telah dibuat.

\section{Uji homogenitas}

Pengujian homogenitas pada sediaan balsem stick dilakukan dengan cara sediaan balsem stick dioleskan pada permukaan objek glass atau bahan transparan lain. Hasil homogenitas yang baik 
ditandai dengan tidak terdapatnya gumpalan pada hasil pengolesan, struktur yang rata dan memiliki warna yang sama dari titik awal pengolesan hingga akhir pengolesan

\section{Uji pH}

Pengukuran nilai $\mathrm{pH}$ dilakukan menggunakan alat $\mathrm{pH}$ meter dengan cara dicelupkan ke dalam $0,5 \mathrm{~g}$ sediaan yang telah diencerkan dengan $5 \mathrm{~mL}$ aquadest. Nilai $\mathrm{pH}$ balsam yang baik adalah 4,5-6,5.

\section{Uji iritasi}

Pengujian ini dilakukan dengan cara mengoleskan sediaan balsem stick pada kulit lengan, kemudian dibiarkan selama 30-60 menit dan diamati reaksi kulit yang terjadi. Reaksi iritasi ditandai oleh adanya ruam, pembengkakan, gatal, atau adanya benjolan kecil di daerah yang diberi perlakuan.

\section{Uji Kesukaan}

Pengujian ini dilakukan pada panelis yang bersangkutan yang dipilih secara acak sebanyak 15 orang. Uji ini dilakukan dengan satu pengujian, parameter kesukaan yang dilihat adalah aroma, tingkat kehangatan dan efek terapi yang dirasakan panelis pada sediaan balsem stick.

\section{HASIL DAN PEMBAHASAN}

\section{a. Hasil Pemeriksaan Simplisia}

Hasil Pemeriksaan Organoleptis Simplisia

Hasil pemeriksaan organoleptis dari simplisia daun sereh yaitu daun berwarna kecoklatan, berbau aromatik, berasa sepat dan sedikit pedas.

Hasil Karakterisasi Simplisia

Sebelum diambil minyak atsiri untuk dibuat menjadi sediaan balsem stick, terlebih dahulu daun sereh tersebut dikarakterisasi. Hasil karakterisasi dapat dilihat pada Table 2.

Tabel 2. Hasil karakterisasi simplisia daun sereh

(Cymbopogon citratus (DC.) Stapf)

\begin{tabular}{|c|c|c|}
\hline No. & $\begin{array}{c}\text { Karakteristik } \\
\text { Simplisia }\end{array}$ & $\begin{array}{l}\text { Hasil } \\
(\%)\end{array}$ \\
\hline 1. & Penetapan kadar air & 9,17 \\
\hline 2. & $\begin{array}{l}\text { Penetapan kadar } \\
\text { sari yang larut } \\
\text { dalam air }\end{array}$ & 20,07 \\
\hline 3. & $\begin{array}{l}\text { Penetapan kadar } \\
\text { sari yang larut } \\
\text { dalam etanol }\end{array}$ & 20,21 \\
\hline 4. & $\begin{array}{c}\text { Penetapan kadar } \\
\text { abu total }\end{array}$ & 4,12 \\
\hline 5. & $\begin{array}{l}\text { Penetapan kadar } \\
\text { abu yang tidak larut } \\
\text { dalam asam }\end{array}$ & 0,44 \\
\hline \multicolumn{3}{|c|}{$\begin{array}{l}\text { Berdasarkan FHI, kadar air } \\
\text { k lebih dari } 10 \% \text {; kadar sari } \\
\text { g larut dalam air tidak kurang } \\
18 \% \text {; kadar sari yang larut } \\
\text { m etanol tidak kurang dari } \\
5 \% \text {; kadar abu total tidak lebih } \\
6 \% \text {; dan kadar abu yang tidak } \\
\text { t dalam asam tidak lebih dari } \\
\% \text {. Dan hasil yang didapat dari } \\
\text { heriksaan karakterisasi simplisia } \\
\text { n sereh telah memenuhi syarat. }\end{array}$} \\
\hline
\end{tabular}




\section{Hasil Skrining Simplisia}

Uji pemeriksaan fitokimia merupakan metode yang dilakukan untuk mengetahui ada tidaknya kandungan fitokimia dalam sampel yang akan di ujikan. Selain mengandung minyak atsiri pada simplisia daun sereh terdapat juga senyawa alkaloid, flavonoid, saponin dan steroid.

Hasil Pengambilan Minyak Atsiri

Pada penelitian ini, proses pengambilan minyak atsiri sereh yang dilakukan dengan metode destilasi tidak mendapatkan hasil minyak atsiri sereh seperti yang diharapkan. Hal ini dikarenakan alat yang digunakan dalam proses penarikan minyak atsiri tidak sesuai. Pada penelitian yang dilakukan, alat yang digunakan adalah alat destilasi sederhana, sedangkan untuk alat destilasi yang umumnya digunakan untuk menarik minyak atsiri adalah alat destilasi uap atau alat destilasi air. Dan untuk tetap kembali melanjutkan penelitian ini yaitu pembuatan sediaan balsem stick, perolehan minyak atsiri yang dibutuhkan di dapat dengan membeli sampel minyak atsiri sereh.

\section{b. Hasil Evaluasi Sediaan Balsem Stick}

\section{Hasil Uji Organoleptis Sediaan}

Hasil uji organoleptis sediaan balsem stick dari ke empat formulasi menghasilkan bentuk dan warna yang sama yaitu, dengan bentuk sediaan semi padat dan warna yang dihasilkan adalah warna putih, untuk aroma yang dihasilkan formulasi 1 dengan tanpa penambahan minyak atsiri sereh menghasilkan aroma menthol saja, untuk formulasi 2, formulasi 3 dan formulasi 4 memiliki aroma khas minyak sereh, dimana semakin tinggi konsentrasi minyak atsiri sereh, maka aroma minyak atsiri sereh juga akan semakin kuat.

\section{Hasil Uji Homogenitas Sediaan}

Hasil pengujian homogenitas dari empat formulasi sediaan balsem stick, yaitu pada konsentrasi $0 \%, 15 \%, 20 \%$ dan $25 \%$ sudah homogen karna hasil yang didapat tidak adanya gumpalan saat dioleskan di atas objek glass. Hal ini membuktikan bahwa semua formulasi sediaan balsem stick yang telah dibuat memiliki homogenitas yang baik.

Hasil Uji pH

\section{Tabel 2. Hasil pengujian pH pada sediaan balsem stick}

\begin{tabular}{cc}
\hline Sediaan & $\begin{array}{c}\text { pH } \\
\text { Sediaan }\end{array}$ \\
\hline $\begin{array}{c}\text { F1 (0\% Minyak atsiri } \\
\text { sereh) }\end{array}$ & 5,35 \\
F2 (15\% Minyak atsiri \\
sereh)
\end{tabular}


yang didapat telah sesuai dengan $\mathrm{pH}$ kulit manusia yaitu antara 4,56,5 dan dengan hasil ini sediaan balsem stick layak untuk digunakan.

\section{Hasil Uji Iritasi}

Hasil uji iritasi yang dilakukan pada ke 15 panelis menunjukkan bahwa setiap formulasi dari sediaan balsem stick sebagai aromaterapi yang telah dibuat tidak memberikan reaksi iritasi, baik reaksi kemerahan ataupun pembengkakan pada bagian lengan yang dioleskan, sehingga dapat disimpilkan bahwa sediaan balsem stick aman untuk digunakan.

\section{Tabel 3. Hasil uji iritasi pada sediaan balsem stick}

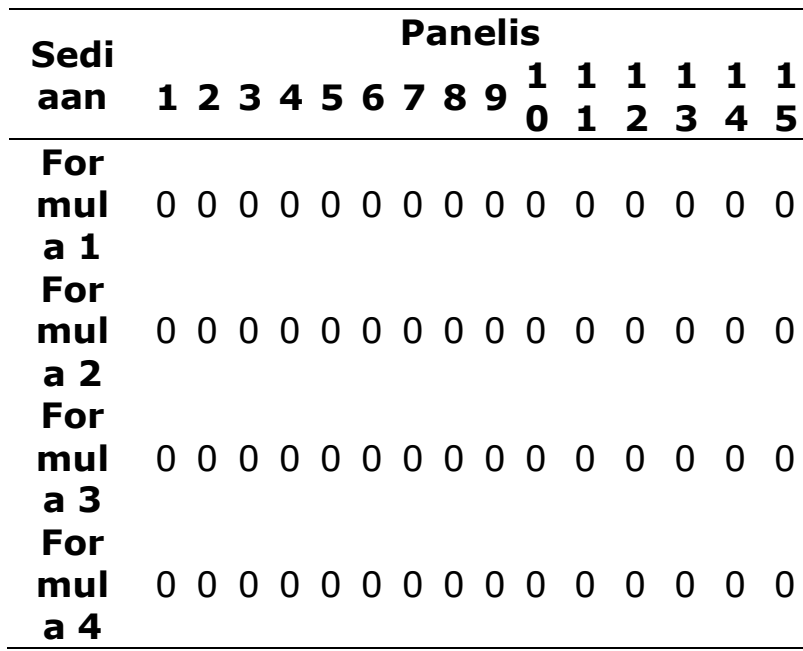

\section{Hasil Uji Kesukaan}

Gambar 2. Grafik hasil uji

kesukaan pada sediaan balsem stick

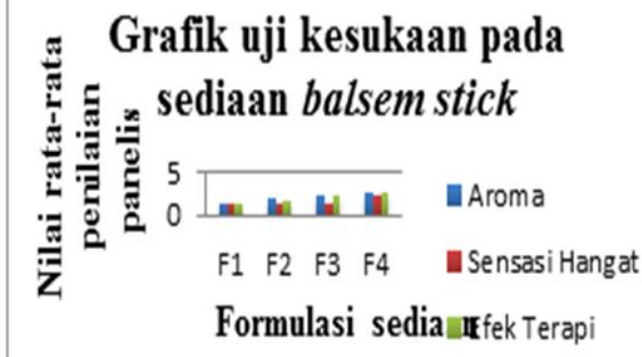

Hasil nilai dengan persentase tertinggi terdapat pada sediaan balsem stick pada formulasi 4 yang memiliki konsentrasi $25 \%$ dengan penambahan minyak atsiri sereh sebanyak $5 \mathrm{ml}$. Sediaan balsem stick dengan konsentrasi $25 \%$ lebih banyak disukai karena aroma khas minyak sereh yang dihasilkan lebih tajam dan efek terapi yang dirasakan seperti rasa hangat dan menenangkan membuat panelis banyak memilih sediaan pada formulasi 4 dibandingkan dengan ke 3 formulasi yang lain dengan konsentrasi $0 \%, 15 \%$ dan $20 \%$.

\section{KESIMPULAN}

Minyak atsiri sereh dapat dibuat menjadi sediaan balsem stick dengan berbagai konsentrasi, yaitu $15 \%$, 20\% dan 25\%. Balsem stick dari minyak atsiri sereh dapat memberikan efek aromaterapi yang ditandai dengan aroma menyegarkan saat menghirup sediaan balsem dan dapat memberikan sensasi hangat. Konsentrasi yang paling baik sebagai sediaan balsem stick aromaterapi adalah $25 \%$ karena 
memberikan aroma dan uji kesukaan paling tinggi berdasarkan hasil dari uji kesukaan yang telah dilakukan pada 15 panelis.

\section{DAFTAR PUSTAKA}

Depkes RI. (1989). Materia Medika Indonesia. Jilid V. Jakarta: Direktorat. Jendral Pengawasan Obat dan Makanan. Halaman 1246-1247

Ditjen POM RI. (1979). Farmakope Indonesia. Edisi III. Jakarta: Departemen Kesehatan RI. Halaman 33

Hendrik, W., Erwin., Panggabean, S, A. (2013). Pemanfaatan Tumbuhan Serai Wangi (Cymbopogon nardus (L.) Rendle) Sebagai Antioksidan Alami. Samarinda: Jurnal Kimia Mulawarman. Vol.10 No.2. Halaman 74-76

Jaelani. (2009). Aroma Terapi. Jakarta: Pustaka Populer Obor.

Jumardin, W., Amin, S., Syahdan, M, N. (2015). Formulasi Sediaan Balsem dari Ekstrak Daun Kemangi (Ocimum Sanctum Linn) dan Pemanfaatannya Sebagai Obat Tradisioanal. As-Syifaa. Vol.07 (01). Halaman 70-72

Lindani, A. (2016). Perbandingan Pengukuran Kadar Air Metode Moisture Analyzer Dengan Metode Oven Pada Produk
Biskuit Sandwich Cookies Di Pt Mondelez Indonesia Manufacturing. Bogor: Departemen IImu Dan Teknologi Pangan Fakultas Teknologi Pertanian Institut Pertanian Bogor. Halaman 11

Pibriani, E., Melany, D., Mulyo, H, T dan Kurniawan, T, M. (2012). Balsem Jahe Stick Usaha Pengoptimalan Pemanfaatan Rempah Jahe Melalui Balsem Sebagai Alternatifnya. Yogyakarta: PKMK 2-12-1. Halaman 1-2

Prabandari, S., Febriyanti, R. (2017). Formulasi dan Aktivitas Kombinasi Minyak Jeruk dan Minyak Sereh pada Sediaan Lilin Aromaterapi. Tegal: Jurnal Para Pemiki. Volume 6. Nomor 1. Halaman 124-125

Yati, K., Dwita, P, L., Oktaviana, L dan Gantini, N, V. (2018). Perbandingan Penggunaan Minyak Zaitun, VCO dan Minyak Jojoba Terhadap Sifat Fisik Balsem Stick Jintan Hitam (Nigella sativa L.) dan Aktivitas Antiinflamasi Subkutan. Makassar: Prosiding Kolokium Doktor dan Seminar Hasil Penelitian Hibah. Halaman 564-565

Zulkarnain, I., Aminullah. (2012). Formulasi Minyak-Minyak Menguap Menjadi Sediaan Balsem Counterirritant. Makassar: As-Syifaa. Volume 04. Nomor 01. Halaman 32-34 